University of Nebraska - Lincoln

DigitalCommons@University of Nebraska - Lincoln

10-2009

\title{
Comparative Life Cycles and Life Histories of North American Rhabdias spp. (Nematoda: Rhabdiasidae): Lungworms from Snakes and Anurans
}

Gabriel J. Langford

Florida Southern College, farancia@gmail.com

John J. Janovy Jr.

University of Nebraska - Lincoln, jjanovy1@unl.edu

Follow this and additional works at: https://digitalcommons.unl.edu/bioscijanovy

Part of the Parasitology Commons

Langford, Gabriel J. and Janovy, John J. Jr., "Comparative Life Cycles and Life Histories of North American Rhabdias spp. (Nematoda: Rhabdiasidae): Lungworms from Snakes and Anurans" (2009). John Janovy Publications. 54.

https://digitalcommons.unl.edu/bioscijanovy/54

This Article is brought to you for free and open access by the Papers in the Biological Sciences at DigitalCommons@University of Nebraska - Lincoln. It has been accepted for inclusion in John Janovy Publications by an authorized administrator of DigitalCommons@University of Nebraska - Lincoln. 


\title{
COMPARATIVE LIFE CYCLES AND LIFE HISTORIES OF NORTH AMERICAN RHABDIAS SPP. (NEMATODA: RHABDIASIDAE): LUNGWORMS FROM SNAKES AND ANURANS
}

\author{
Gabriel J. Langford and John Janovy, Jr. \\ School of Biological Sciences, University of Nebraska-Lincoln, Lincoln, Nebraska 68588. e-mail: farancia@gmail.com
}

\begin{abstract}
The present study used experimental infections to compare the life cycles and life histories of 6 Rhabdias spp. infecting snakes and anurans. Free-living development of anuran lungworms was primarily limited to heterogonic reproduction, and females utilized matricidal endotoky exclusively, whereas snake lungworms primarily reproduced homogonically and, when heterogonic reproduction occurred, females used a combination of releasing eggs and matricidal endotoky. Infective snake lungworms survived for longer periods in fresh water compared to anuran worms. Infective anuran lungworms penetrated into the skin of frogs and toads; few infections resulted from per os infections. In contrast, snake lungworms were unable to penetrate skin; instead, infective juveniles penetrated into snake esophageal tissue during per os infections. Despite separate points of entry, anuran and snake lungworms both migrated and developed in the fascia, eventually penetrating into the body cavity of the host. Worms molted to adulthood inside the body cavity and subsequently penetrated into the host's lungs, where they fed on blood while becoming gravid. Adult lungworm survival varied among lungworm species, but, in general, snake lungworms were longer lived than anuran worms. Anuran lungworms were poorly suited for transmission via transport hosts, whereas snake lungworms were consistently capable of establishing infections using transport hosts. Overall, these observations suggest that snake and anuran lungworms have discrepant life cycles and life history strategies.
\end{abstract}

Comparative approaches in life cycle and life history research are useful in revealing life cycle variations between closely related parasites (Morand and Poulin, 2003; Lefebvre and Poulin, 2005; Poulin, 2007; Bolek et al., 2009). Using the comparative method, Snyder and Janovy (1994), Bolek and Janovy (2007a, 2007b; 2008), and Bolek et al. (2009) found that closely related parasites can and do use discrepant evolutionary avenues to complete their life cycles. These studies suggest life cycle variation is more common than previously assumed, at least in trematodes from anuran hosts. However, the pervasiveness of life cycle variation is unclear, because our understanding is limited to a few studies and parasites. Additional studies are needed to compare life cycles and life histories among closely related taxa infecting phylogenetically diverse and broadly distributed hosts. Species of Rhabdias fulfill these requirements and permit use of amphibian and reptilian hosts, which provide model host systems for studying life cycle evolution (see Bolek and Janovy, 2007a).

Species of the cosmopolitan nematode, Rhabdias Stiles and Hassall, 1905, are among the most common metazoan parasites of amphibians and reptiles. The life cycles of these nematodes alternate between parasitic and free-living generations. Parasitic individuals are protandrous hermaphrodites that produce spermatozoa in a "testis zone" prior to, and sometimes continuing through, egg development (Runey et al., 1978). Eggs are transported from the host's lungs into the gastrointestinal tract, where they are defecated into the soil, hatch, and begin a freeliving generation. The free-living generation was initially thought to undergo only heterogonic reproduction, i.e., male and female sexual reproduction (Mecznikow, 1865; Goodey, 1924; Schaake, 1931). However, in homogonic stages, i.e., juveniles that forego sex and molt to an infective stage, development also occurs (Railliet, 1899; Goodey, 1924; Walton, 1929; Chu, 1936; Baker, 1979); Chu (1936) found both homogonic and heterogonic development in some cultures of Rhabdias fuscovenosa. Regardless of developmental route, infective juveniles enter host body cavities via skin penetration (Baker, 1979), orally (Chu, 1936), or

Received 30 January 2009; revised 24 March 2009; accepted 3 April 2009.

DOI: 10.1645/ GE-2044.1 potentially via a transport host (Baker, 1979), and eventually establish themselves as adults in the lungs.

Since the work of Chu (1936) and Baker (1979), little experimental research has been conducted on the life cycles and life histories of parasitic and free-living generations in Rhabdias spp. (but see Spieler and Schierenberg, 1995). Life cycles of several North American species remain unexplored, and some aspects of previously described life cycles remain unsubstantiated. Given their lack of study, global distribution, and varied hosts, lungworms appear to be an ideal place to search for life cycle variation. Furthermore, the increasing popularity of lungworms as ideal host-parasite models to test evolutionary principles and ecological interactions (e.g., Goater, 1992, 1994; Goater and Ward, 1992; Christin et al., 2003; Gendron et al., 2003; Dare and Forbes, 2008a, 2008b) warrants a greater understanding of the worms' life histories. Our goal is to elucidate and compare the life cycles and life history characteristics of several Rhabdias spp. that infect snakes and anurans occurring in the United States and Canada.

\section{MATERIALS AND METHODS}

\section{Amphibian and reptile field studies}

Anurans and snakes were captured from May 2005 to June 2008 during both day and night using hand capture, pit-fall traps, funnel traps, drift fences, and by cruising roads (Heyer et al., 1994). Animals were transported to either the parasitology laboratory at the University of Nebraska-Lincoln, Cedar Point Biological Station in western Nebraska, or the vertebrate museum at the University of South Alabama, where they were killed and measured for snout-vent length (SVL) and total length (TL), and all organs were examined for parasites within $48 \mathrm{hr}$ of collection. Rhabdias spp. were removed and fixed in hot $70 \%$ ethyl alcohol; however, many adult hermaphrodites were set aside for use in life cycle experiments (see below). Representative specimens were cleared and temporarily mounted in glycerol for identification (Prichard and Kruse, 1982). All lungworms were identified according to Kuzmin et al. (2003).

Rhabdias americanus Baker, 1978, were harvested from Bufo (Anaxyrus) terrestris collected from the University of South Alabama campus, Mobile County, Alabama $\left(30^{\circ} 42^{\prime} 7^{\prime \prime},-88^{\circ} 11^{\prime} 17^{\prime \prime}\right)$; Rhabdias bakeri Tkach, Kuzmin, Pulis, 2006, from Rana (Lithobates) sylvatica collected in Jefferson County, Missouri ( $\left.38^{\circ} 21^{\prime} 35^{\prime \prime},-90^{\circ} 24^{\prime} 0^{\prime \prime}\right)$; Rhabdias joaquinensis Ingles, 1935 from Acris crepitans collected in Pawnee Lake, Lancaster County, Nebraska $\left(40^{\circ} 50^{\prime} 35^{\prime \prime},-96^{\circ} 31^{\prime} 33^{\prime \prime}\right)$; Rhabdias ranae Walton, 1929, from Rana (Lithobates) sphenocephala collected in Baldwin County, Alabama $\left(30^{\circ} 27^{\prime} 28^{\prime \prime},-87^{\circ} 25^{\prime} 59^{\prime \prime}\right)$; Rhabdias eustreptos (McCallum, 1921) 
from Lampropeltis getulus collected in the Grand Bay National Estuarine Research Reserve, Jackson County, Mississippi (30 $\left.26^{\prime} 10^{\prime \prime},-88^{\circ} 25^{\prime} 58^{\prime \prime}\right)$; and Rhabdias fuscovenosa (Railliet, 1899) from Thamnophis sirtalis collected in Keith County, Nebraska $\left(41^{\circ} 18^{\prime} 19^{\prime \prime},-101^{\circ} 55^{\prime} 43^{\prime \prime}\right)$. Voucher specimens have been deposited in the H. W. Manter Parasitology Collection, University of Nebraska, Lincoln, Nebraska (accession numbers HWML 63512 Rh. americanus, 63513 Rh. bakeri, $63514 R h$. eustreptos, 63515 Rh. fuscovenosa, $63516 R h$. joaquinensis, and $63517 R h$. ranae).

\section{Culturing lungworms in the laboratory}

For this study, Chu (1936) was modified to provide an inexpensive, quick method for producing a large number of infective juveniles in a consistent manner. Culturing containers were constructed with a $10-\mathrm{cm}$ diameter circular piece of unbleached paper towel, with a 2-cm diameter circle cut in the middle, thus forming a paper towel donut. This donut permitted viewing of lungworm development without disturbing culture conditions. Next, the donut was dampened with aged tap water and handmolded to the inside of a 5-cm Petri dish. The Petri dish was placed inside a larger $(9 \mathrm{~cm})$ Petri dish, and covered with a lid. Approximately $20 \mathrm{ml}$ of aged tap water was added to the larger dish, thus forming a shallow water bath for the smaller container. Two grams of feces were added to the inner Petri dish to establish bacterial colonies for food. Finally, eggs were placed inside the small Petri dish adjacent to the feces. Cultures were kept at $26 \mathrm{C}$ for all experiments.

The development of free-living juveniles was easily observed. After a few days, infective juveniles migrated out of the small, inner Petri dish to reside in the outer Petri dish. Infective juveniles were easily maintained by removing the inner container following nematode migration. Water exchanges were necessary to prevent premature death of infective juveniles, due to stale water exposure (Chu, 1936). Petri dish lids also were removed for 5-10 min daily to provide gas exchange. Accidental inoculation of cultures with predators (mites and fungi) was avoided to a certain degree by centrifuging the feces and extracting the supernatant for bacteria (Spieler and Schierenberg, 1995). However, centrifuged cultures produced fewer infective juveniles than non-centrifuged ones; this technique was thus abandoned early in the research. Instead, cultures were inoculated with nematode-free feces and periodically checked for predacious mites and fungi, which were promptly removed. The latter method was time consuming, but produced the greatest numbers of infective juveniles.

\section{Acquiring uninfected hosts}

Uninfected amphibians were obtained from Cedar Point Biological Station (CPBS) in western Nebraska (in $>30 \mathrm{yr}$ of constant sampling, no amphibians were infected with Rhabdias spp. [J. Janovy, Jr., pers. obs.]) Uninfected Bufo (Anaxyrus) woodhousii, Rana (Lithobates) pipiens, and Rana (Lithobates) blairi were collected from CPBS. All other hosts used were obtained from areas where lungworms were potentially transmitted. These animals were placed individually in cages, and their feces were checked for juvenile Rhabdias spp. at 0 and 10-20 days. This time period permitted maturing of any infection the hosts may have obtained prior to capture, thus assuring only uninfected hosts were used in experiments. Other uninfected hosts were acquired by rearing uninfected tadpoles in the laboratory or isolating wild, gravid snakes in the laboratory and housing offspring in cages that prevented transmission.

\section{Free-living experiments}

Adult hermaphrodites were collected from lungs of captured wild hosts Eggs released were pipetted into culture containers, with each receiving eggs from 6 to 7 adult worms. Cultures were checked every 2-3 hr to record developmental stage. Growth and timing of free-living juveniles were recorded by measuring total length, maximum width, esophagus length, and tail length of 10 specimens from each of the following stages: first stage juveniles, adult males and females, and third stage infective juveniles. The number of eggs per female was recorded for all measured specimens; however, only approximate egg counts were possible for $R h$. eustreptos and Rh. fuscovenosa because both species undergo partial matricidal endotoky, where females release some eggs prior to death (ca. $4-5$ ), and remaining eggs hatch in utero and undergo typical matricidal endotoky. The remaining 4 species never released eggs; therefore, egg counts were exact.

Numbers of infective juveniles produced by homogonic vs. heterogonic development were also recorded. Homogonic worms invariably, and rapidly, self separated, i.e., migrated into the outer water bath, prior to worms that developed heterogonically. Temporal variation in self separation allowed homogonic worms to be counted and placed in separate Petri dishes prior to emergence of heterogonic worms. After all infective worms migrated into the water bath, inner containers were removed from the culture container. Containers were considered viable if at least 1 infective juvenile remained alive.

\section{Host experimental exposures}

Infective lungworms used in snake and anuran host exposures were obtained using the modified culture chambers. Hosts were exposed to lungworms via skin penetration and orally to test the route(s) of infection used by each species. In skin exposures, infective worms were placed on a 9-cm diameter piece of moist, unbleached paper towel that was positioned on the bottom of a glass culture dish with a breathable glass lid. Hosts were placed individually in the infection chamber, where they remained for $12 \mathrm{hr}$; upon removal, hosts were rinsed thoroughly in aged tap water to remove any remaining nematodes. Host drinking was a concern in skin exposure experiments for snakes, but not anurans, since they do not acquire water orally (Pough et al., 2004). To prevent snakes from consuming nematodes orally, they were fitted with a $6-\mathrm{cm}$ soft plastic collar around the neck. The collar allowed for normal movement and breathing, but kept the head of the snake dry. In the per os experiments, infective juveniles were intubated into the esophagus along with $5 \mathrm{ml}$ of aged tap water. Hosts were then rinsed in aged tap water to remove any juveniles that may have been pipetted onto the hosts' skin.

Depending on cannibalistic tendencies, hosts were housed individually or in small groups; they were provided access to fresh water and refugia. Snakes were fed frozen, thawed white fish (Tilapia sp.) and mice; anurans were fed a diet of commercial crickets (Top Hat Cricket Farm, Kalamazoo, Michigan) and cultured mealworms (Janovy Laboratory, University of Nebraska-Lincoln). Hosts were exposed to an appropriate temperature gradient and a 12-hr day/light cycle. Cages were lined with absorbent paper towels and cleaned 2-3 times per week to prevent development of infective juveniles in host feces and potential transmission of lungworms passed in feces from the per os experiment. All hosts were exposed to 30 infective juveniles. Host specificity problems were avoided by matching host species with appropriate Rhabdias spp. based on natural infections reported by Kuzmin et al. (2003) or found during this study. All experimental infection protocols used the following exposure combinations, B. woodhousii and Rh. americanus; Ra. sylvatica and Rh. bakeri; A. crepitans and $R h$. joaquinensis; Ra. pipiens and $R h$. ranae; and Thamnophis sauritus and Rh. eustreptos or Rh. fuscovenosa.

Separate trials were conducted on host experimental exposures to determine the route and timing of development and morphological growth of the worms. In trial 1, hosts were exposed to lungworms using both per os and skin exposure and subsequently dissected. All organs, muscles, body cavities, and connective tissues were thoroughly searched for developing lungworms at regular intervals from 1 to 40 days post-infection (PI) Number and developmental stage of worms was recorded. In trial 1, 4 hosts ( 2 for per os, 2 for skin penetration) were dissected at each time period.

In trial 2, hosts were exposed to infective lungworms, using per os exposures for snakes and skin penetration exposures for anurans. Hosts were dissected and all tissues were thoroughly searched for developing worms at consistent intervals 1-30 days PI. Worms were categorized into the following developmental stages: juvenile (third stage), juvenile (fourth stage), adult (body cavity), adult (lungs), and gravid adult (lungs). Cuticular shedding was noted when possible. Ten worms per stage were selected at random and measured for total length, maximum width, esophagus length, and tail length. In the second trial, 2 hosts were dissected at each interval. Time- 0 and time-T controls were used in both trials to ensure hosts did not develop spurious infections through the course of the experiments.

In trial 3, hosts were kept in clean, lungworm-free containers for extended periods of time to determine the duration of infection for each lungworm species. Containers and methods designed to prevent lungworm transmission (described above) were used throughout the experiment. In addition, host diets were supplemented with appropriate trace nutrients 
during long-term captivity. Anurans and snakes were not hibernated during the study. Hosts were each exposed to 30 infective lungworms (see trial 2), then placed in transmission-free containers. The following combinations of host species (No. of individuals) to parasite species were used in this experiment, B. woodhousii (12) and Rh. americanus; Ra. sylvatica (7) and Rh. bakeri; Pseudacris triseriata (12) and Rh. joaquinensis; Ra. blairi (12) and Rh. ranae; T. sauritus (3) and Rh. eustreptos; T. sauritus (3) and Rh. fuscovenosa.

Fresh host feces were checked for juvenile lungworms twice a week in anuran lungworms and twice a month in snake lungworms. Duration of infection was measured in each host by recording the last date eggs, or juvenile worms, or both, were collected from feces. Two negative fecal samples in succession were used as the stopping point for these experiments. Dissection was used to confirm hosts were uninfected.

\section{Transport hosts}

Infective juveniles of 4 lungworms species were obtained from feces and used to test the efficacy of potential transport hosts. Adult Physa gyrina were collected from Nevin's Pond, Keith County, Nebraska (41.20918, -101.41772 ) and exposed in groups of 10 snails to 150 infective worms 2-3 days post-capture. Snail exposures were conducted in a 9-cm diameter glass culture dish with an unbleached paper towel bottom and breathable glass lid in $1 \mathrm{~cm}$ of aged tap water. After $12 \mathrm{hr}$, snails were removed from the container, placed in clean aquaria, and allowed to void their gut for 12 hr. Four snails were then manually fed to individual hosts, which were exposed in various combinations, $7 \mathrm{~B}$. woodhousii and $R h$. americanus, $7 \mathrm{~A}$. crepitans and Rh. joaquinensis, $3 T$. sauritus and Rh. eustreptos, and $3 T$. sauritus and Rh. fuscovenosa. Anuran and snake hosts were dissected, and all tissues were searched for developing lungworms 8 days post-exposure. Twenty exposed snails were also dissected for all 4 species of lungworm to search for third stage juvenile worms. Snails were provided a diet of frozen spinach, unless otherwise noted.

The earthworm Eisenia foetida and larval Taenibro molitar beetles from domestic stock were allowed to feed ad libitum on host feces containing numerous infective juveniles. After $12 \mathrm{hr}$ earthworms and beetle larvae were placed in clean plastic containers and allowed to void their guts for $12 \mathrm{hr}$. Four beetles were fed to each host in the following combinations, 5 $B$. woodhousii and Rh. americanus, 6 A. crepitans and Rh. joaquinensis, $3 T$. sauritus and Rh. eustreptos, and 3 T. sauritus and Rh. fuscovenosa. Three $T$. sauritus were each fed 4 earthworms exposed to $R h$. eustreptos, and $3 T$. sauritus were each fed 4 earthworms exposed to Rh. fuscovenosa. Anuran and snake hosts were dissected and all tissues were searched for developing lungworms 8 days after being fed earthworms or beetle larvae. Twenty earthworms and 10 beetle larvae were also dissected for all 4 species of lungworm, after earthworms and beetles voided their guts, to search for third stage juvenile worms.

Specimens of Ra. blairi were collected from Lake Pawnee, Lancaster County, Nebraska, and exposed to infective stages of Rh. eustreptos or Rh. fuscovenosa. Six frogs were exposed to $R h$. eustreptos and 6 to $R h$. fuscovenosa via passive exposure in culture dishes. Following the 12-hr exposure, frogs were rinsed and housed individually in plastic containers with access to fresh water and crickets. Frog transport hosts were housed for 7 days prior to being fed to final snake hosts. Six lab-reared T. sauritus were each fed 2 frogs from the same lungworm exposure, kept in the laboratory for 8 days, and dissected to determine the presence of developing lungworms. In addition, 5 frogs exposed to each lungworm species (10 frogs total) were dissected and searched for developing lungworms following parasite exposure and a 7 day resting period. For all transport host experiments, time- 0 and time-T controls were used to ensure normal definitive and transport hosts were not previously infected and did not develop spurious infections during the experiment.

\section{RESULTS}

\section{Free-living development}

Lungworms of snakes: Lungworms ( $R h$. eustreptos, $R h$. fuscovenosa) collected from snakes displayed similar development patterns, except timing of development (Table I). Approximately $50 \%$ of the eggs collected from the lungs of snakes were embryonated; however, $100 \%$ of eggs removed from the lower intestine were embryonated. Lungworm eggs hatched on exposure to air, or fresh water, or both. On the average, Rh. eustreptos developed into third stage homogonic juveniles $(65.8 \mathrm{hr})$ almost twice as fast as $R h$. fuscovenosa $(120 \mathrm{hr})$. Both species displayed homogonic development; heterogonic development occurred in $56 \%$ (10 of 18) of Rh. eustreptos cultures and 40\% (8 of 20) of $R h$. fuscovenosa cultures. In all snake lungworm cultures $<2 \%$ of infective worms developed heterogonically. Infective juveniles acquired from heterogonic development in snakes were morphologically identical to those produced during homogonic development but were unable to infect snakes, whereas hosts exposed to homogonic juveniles developed infections consistently.

Infective lungworms often survived for long periods ( 97 days in 1 culture) as third stage juveniles in Petri dishes with regular water exchange. Infective juveniles in Petri dishes maintained a quiescent state until disturbed. When disturbed by vibration, juvenile worms undulated vigorously for approximately $15 \mathrm{~min}$, and then returned to an inactive state. Desiccation killed freeliving juveniles and adults. Male and female worms were distinctly rhabditiform and easily distinguished from infective juveniles (see Baker, 1979). Mating was only observed on 8 occasions, i.e., the male moved alongside the female and grasped her with his tail. Copulation lasted $<2 \mathrm{~min}$; multiple mating was not observed under normal culture conditions, whereas multiple mating was observed when worm population densities were increased. Freeliving $R$ h. eustreptos females produced approximately 8 eggs, and $R h$. fuscovenosa produced 10 eggs. Males died soon after mating. Eggs released prior to matricidal endotoky hatched quickly in the culture chamber and immediately began feeding on bacteria. In general, juveniles from released eggs developed at a similar rate as those that developed via matricidal endotoky, i.e., outer dish migration times overlapped. Rhabdias eustreptos and Rh. fuscovenosa developed at different rates, yet were of similar size when measured at different developmental stages (Tables II, III).

Lungworms of anurans: Eggs collected from both the lungs and colons of anurans were fully embryonated and hatched upon exposure to air, or fresh water, or both. Lungworms collected from anurans, i.e., $R h$. americanus, $R h$. bakeri, $R h$. joaquinensis, and $R h$. ranae, displayed almost complete heterogonic development (see Table I). The notable exception was heterogonic development by $R h$. joaquinensis; of 23 cultures, 3 produced 8 , 12 , and 17 homogonic juveniles. Infective juveniles acquired from homogonic development in $R h$. joaquinensis were unable to infect $R a$. blairi during skin exposure experiments. Mating was observed on numerous occasions in all species, except $R h$. bakeri. Mating occurred when males aligned themselves parallel to females and grasped the females near the vulva with their tails. Copulation lasted 1-8 $\mathrm{min}$; both males and females mated multiple times, usually with multiple partners. Males, however, died soon after mating. Free-living females of all 4 species produced 2-3 eggs that developed exclusively through matricidal endotoky. Infective juvenile worms varied in maximum survival times from 16 days in $R h$. bakeri to 37 days in $R h$. joaquinensis. Infective juveniles in Petri dishes maintained a quiescent state until disturbed by agitating the Petri dish. When disturbed, juvenile worms behaved similarly to snake lungworms; likewise, worms of these 4 species were unable to survive desiccation. Adult females vary in average total length from $688 \mu \mathrm{m}$ in $R h$. joaquinensis to $778 \mu \mathrm{m}$ in $R h$. ranae (Tables IV-VII). Despite interspecific differences in female size, infective juveniles reached similar total lengths. 


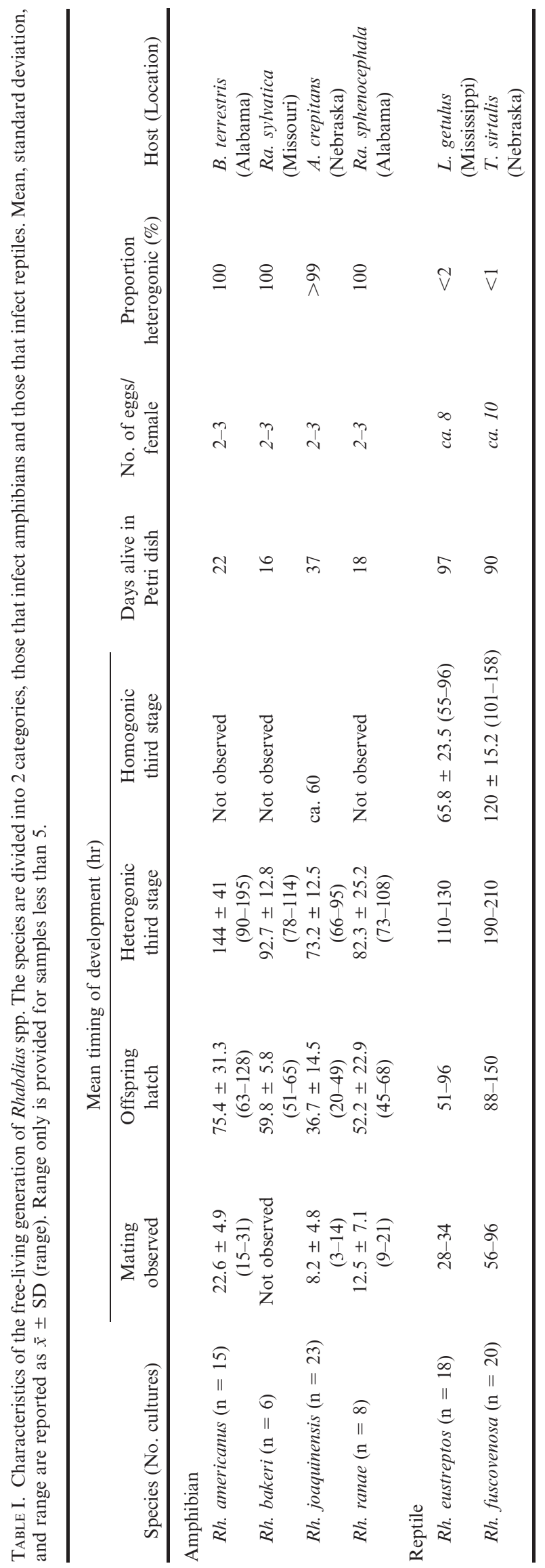


TABLE II. Development of Rhabdias eustreptos experimentally exposed to Thamnophis sauritus. Free-living cultures established from wild Thamnophis sirtalis. Mean \pm SD (range) given in $\mu \mathrm{m}$, unless otherwise noted.

\begin{tabular}{|c|c|c|c|c|c|c|}
\hline & $\begin{array}{l}\text { Free-living } \\
\text { male }\end{array}$ & $\begin{array}{l}\text { Free-living } \\
\text { female }\end{array}$ & $\begin{array}{l}\text { Third stage } \\
\text { (infective) }\end{array}$ & $\begin{array}{l}\text { Adult } \\
\text { (lungs) }\end{array}$ & $\begin{array}{l}\text { Adult gravid } \\
\quad \text { (lungs) }\end{array}$ & $\begin{array}{l}\text { Adult gravid } \\
\quad \text { (lungs) }\end{array}$ \\
\hline Days post-infection & - & - & - & 10 & 18 & 30 \\
\hline No. measured & 10 & 10 & 10 & 10 & 10 & 10 \\
\hline Total length & $\begin{array}{l}534 \pm 23 \\
(500-583)\end{array}$ & $\begin{array}{l}780 \pm 18 \\
(714-836)\end{array}$ & $\begin{array}{l}775 \pm 25 \\
(743-840)\end{array}$ & $\begin{array}{l}3.12 \pm 0.25 \mathrm{~mm} \\
(2.67-3.78)\end{array}$ & $\begin{array}{l}4.33 \pm 0.3 \mathrm{~mm} \\
(3.74-4.7)\end{array}$ & $\begin{array}{l}6.15 \pm 0.15 \mathrm{~mm} \\
(5.67-6.28)\end{array}$ \\
\hline Maximum width & $\begin{array}{l}31 \pm 2 \\
(27-35)\end{array}$ & $\begin{array}{l}43 \pm 6 \\
(35-59)\end{array}$ & $\begin{array}{l}30 \pm 5 \\
(26-44)\end{array}$ & $\begin{array}{l}251 \pm 13 \\
(237-268)\end{array}$ & $\begin{array}{l}339 \pm 20 \\
(298-373)\end{array}$ & $\begin{array}{l}470 \pm 33 \\
(401-494)\end{array}$ \\
\hline Esophagus length & $\begin{array}{l}116 \pm 8 \\
(109-138)\end{array}$ & $\begin{array}{l}130 \pm 8 \\
(120-152)\end{array}$ & $\begin{array}{l}159 \pm 10 \\
(140-177)\end{array}$ & $\begin{array}{l}341 \pm 11 \\
(322-360)\end{array}$ & $\begin{array}{l}359 \pm 6 \\
(337-382)\end{array}$ & $\begin{array}{l}389 \pm 10 \\
(371-401)\end{array}$ \\
\hline Tail length & $\begin{array}{l}29 \pm 4 \\
(21-37)\end{array}$ & $\begin{array}{l}50 \pm 5 \\
(40-75)\end{array}$ & $\begin{array}{l}57 \pm 6 \\
(49-71)\end{array}$ & $\begin{array}{l}213 \pm 21 \\
(198-243)\end{array}$ & $\begin{array}{l}250 \pm 8 \\
(239-276)\end{array}$ & $\begin{array}{l}290 \pm 6 \\
(280-298)\end{array}$ \\
\hline
\end{tabular}

TABLE III. Development of Rhabdias fuscovenosa experimentally exposed to Thamnophis sauritus. Free-living cultures established from wild Lampropeltis getulus. Mean $\pm \mathrm{SD}$ (range) given in $\mu \mathrm{m}$, unless otherwise noted.

\begin{tabular}{|c|c|c|c|c|c|c|}
\hline & $\begin{array}{c}\text { Free-living } \\
\text { male }\end{array}$ & $\begin{array}{c}\text { Free-living } \\
\text { female }\end{array}$ & $\begin{array}{l}\text { Third stage } \\
\text { (infective) }\end{array}$ & $\begin{array}{l}\text { Adult } \\
\text { (lungs) }\end{array}$ & $\begin{array}{l}\text { Adult gravid } \\
\text { (lungs) }\end{array}$ & $\begin{array}{l}\text { Adult gravid } \\
\text { (lungs) }\end{array}$ \\
\hline Days post-infection & - & - & - & 14 & 20 & 30 \\
\hline No. measured & 10 & 10 & 10 & 10 & 10 & 10 \\
\hline Total length & $\begin{array}{l}575 \pm 43 \\
(514-629)\end{array}$ & $\begin{array}{l}796 \pm 41 \\
(705-850)\end{array}$ & $\begin{array}{l}756 \pm 20 \\
(740-810)\end{array}$ & $\begin{array}{l}2.13 \pm 0.19 \mathrm{~mm} \\
(2.01-2.45)\end{array}$ & $\begin{array}{l}3.61 \pm 0.08 \mathrm{~mm} \\
(3.54-3.78)\end{array}$ & $\begin{array}{l}4.1 \pm 0.11 \mathrm{~mm} \\
(3.89-4.21)\end{array}$ \\
\hline Maximum width & $\begin{array}{l}31 \pm 3 \\
(25-37)\end{array}$ & $\begin{array}{l}45 \pm 5 \\
(33-55)\end{array}$ & $\begin{array}{l}30 \pm 4 \\
(23-39)\end{array}$ & $\begin{array}{l}126 \pm 22 \\
(116-141)\end{array}$ & $\begin{array}{l}143 \pm 20 \\
(133-160)\end{array}$ & $\begin{array}{l}156 \pm 6 \\
(149-166)\end{array}$ \\
\hline Esophagus length & $\begin{array}{l}120 \pm 5 \\
(111-127)\end{array}$ & $\begin{array}{l}132 \pm 6 \\
(122-148)\end{array}$ & $\begin{array}{l}153 \pm 9 \\
(141-178)\end{array}$ & $\begin{array}{l}261 \pm 14 \\
(242-288)\end{array}$ & $\begin{array}{l}284 \pm 11 \\
(259-301)\end{array}$ & $\begin{array}{l}280 \pm 12 \\
(272-300)\end{array}$ \\
\hline Tail length & $\begin{array}{l}30 \pm 5 \\
(21-40)\end{array}$ & $\begin{array}{l}52 \pm 6 \\
(43-76)\end{array}$ & $\begin{array}{l}55 \pm 7 \\
(41-65)\end{array}$ & $\begin{array}{l}123 \pm 14 \\
(111-153)\end{array}$ & $\begin{array}{l}168 \pm 18 \\
(134-201)\end{array}$ & $\begin{array}{l}180 \pm 11 \\
(174-205)\end{array}$ \\
\hline
\end{tabular}

\section{Parasite development}

Lungworms of snakes: Infective worms remained quiescent in culture chambers, until the Petri dish was disturbed by vibrations or the worms were prodded with forceps. On disturbance, worms responded similarly to anuran species (see below). During skin exposure experiments, infective juveniles were unable to penetrate the skin of $T$. sauritus. Infective worms continuously undulated over the surface of the snake, but worms established infections only when they entered the host's oral cavity. Infections were always established in per os infections. Following oral intubation, snake lungworms penetrated (or were in the process of) the esophagus and resided in the connective tissue of the esophagus. Penetration occurred throughout the entire esophagus, but primarily in the striated muscle of the anterior half. Next, worms molted to fourth stage juveniles, with no sheath. Both third and fourth stage juveniles were recovered from connective tissue that surrounded the esophagus, trachea, gastrointestinal tract, liver,

TABLE IV. Development of Rhabdias americanus experimentally exposed to Bufo woodhousii. Free-living cultures established from wild Bufo terrestris. Mean \pm SD (range) given in $\mu \mathrm{m}$, unless otherwise noted.

\begin{tabular}{|c|c|c|c|c|c|c|}
\hline & $\begin{array}{l}\text { Free-living } \\
\text { male }\end{array}$ & $\begin{array}{l}\text { Free-living } \\
\text { female }\end{array}$ & $\begin{array}{l}\text { Third stage } \\
\text { (infective) }\end{array}$ & $\begin{array}{l}\text { Adult } \\
\text { (lungs) }\end{array}$ & $\begin{array}{l}\text { Adult gravid } \\
\quad \text { (lungs) }\end{array}$ & $\begin{array}{l}\text { Adult gravid } \\
\quad \text { (lungs) }\end{array}$ \\
\hline Days post-infection & - & - & - & 9 & 18 & 30 \\
\hline No. measured & 10 & 10 & 10 & 10 & 10 & 10 \\
\hline Total length & $\begin{array}{l}534 \pm 32 \\
(489-598)\end{array}$ & $\begin{array}{l}745 \pm 21 \\
(700-761)\end{array}$ & $\begin{array}{l}483 \pm 43 \\
(414-554)\end{array}$ & $\begin{array}{l}4.89 \pm 0.34 \mathrm{~mm} \\
\quad(3.8-5.6)\end{array}$ & $\begin{array}{l}6.85 \pm 0.54 \mathrm{~mm} \\
\quad(5.2-7.21)\end{array}$ & $\begin{array}{l}9.23 \pm 0.53 \mathrm{~mm} \\
(8.76-10.03)\end{array}$ \\
\hline Maximum width & $\begin{array}{l}33 \pm 3 \\
(29-35)\end{array}$ & $\begin{array}{l}42 \pm 2 \\
(39-45)\end{array}$ & $\begin{array}{l}20 \pm 2 \\
(17-25)\end{array}$ & $\begin{array}{l}126 \pm 18 \\
(103-158)\end{array}$ & $\begin{array}{l}189 \pm 21 \\
(156-201)\end{array}$ & $\begin{array}{l}243 \pm 28 \\
(227-266)\end{array}$ \\
\hline Esophagus length & $\begin{array}{l}108 \pm 4 \\
(100-111)\end{array}$ & $\begin{array}{l}146 \pm 6 \\
(138-159)\end{array}$ & $\begin{array}{l}150 \pm 22 \\
(120-182)\end{array}$ & $\begin{array}{l}430 \pm 38 \\
(411-454)\end{array}$ & $\begin{array}{l}523 \pm 46 \\
(501-559)\end{array}$ & $\begin{array}{l}712 \pm 54 \\
(640-742)\end{array}$ \\
\hline Tail length & $\begin{array}{l}32 \pm 3 \\
(26-36)\end{array}$ & $\begin{array}{l}49 \pm 5 \\
(42-56)\end{array}$ & $\begin{array}{l}42 \pm 7 \\
(32-55)\end{array}$ & $\begin{array}{l}156 \pm 24 \\
(142-183)\end{array}$ & $\begin{array}{l}247 \pm 29 \\
(235-288)\end{array}$ & $\begin{array}{l}344 \pm 41 \\
(305-367)\end{array}$ \\
\hline
\end{tabular}


TABle V. Development of Rhabdias bakeri experimentally exposed to Rana sylvatica. Free-living cultures established from wild Rana sylvatica. Mean \pm $\mathrm{SD}$ (range) given in $\mu \mathrm{m}$, unless otherwise noted.

\begin{tabular}{|c|c|c|c|c|c|c|}
\hline & $\begin{array}{c}\text { Free-living } \\
\text { male }\end{array}$ & $\begin{array}{l}\text { Free-living } \\
\text { female }\end{array}$ & $\begin{array}{l}\text { Third stage } \\
\text { (infective) }\end{array}$ & $\begin{array}{l}\text { Adult } \\
\text { (lungs) }\end{array}$ & $\begin{array}{l}\text { Adult gravid } \\
\quad \text { (lungs) }\end{array}$ & $\begin{array}{l}\text { Adult gravid } \\
\quad \text { (lungs) }\end{array}$ \\
\hline Days post-infection & - & - & - & 9 & 17 & 30 \\
\hline No. measured & 10 & 10 & 10 & 10 & 8 & 10 \\
\hline Total length & $\begin{array}{l}501 \pm 33 \\
(466-553)\end{array}$ & $\begin{array}{l}748 \pm 24 \\
(712-780)\end{array}$ & $\begin{array}{c}490 \pm 30 \\
(433-566)\end{array}$ & $\begin{array}{l}3.03 \pm 0.22 \mathrm{~mm} \\
(2.84-3.46)\end{array}$ & $\begin{array}{l}4.22 \pm 0.26 \mathrm{~mm} \\
(3.95-4.50)\end{array}$ & $\begin{array}{l}7.24 \pm 0.09 \mathrm{~mm} \\
(6.93-7.49)\end{array}$ \\
\hline Maximum width & $\begin{array}{l}33 \pm 2 \\
(28-36)\end{array}$ & $\begin{array}{l}49 \pm 5 \\
(44-59)\end{array}$ & $\begin{array}{l}20 \pm 2 \\
(18-22)\end{array}$ & $\begin{array}{l}94 \pm 9 \\
(85-110)\end{array}$ & $\begin{array}{l}127 \pm 6 \\
(114-137)\end{array}$ & $\begin{array}{l}134 \pm 4 \\
(119-139)\end{array}$ \\
\hline Esophagus length & $\begin{array}{l}112 \pm 4 \\
(104-115)\end{array}$ & $\begin{array}{l}146 \pm 9 \\
(133-157)\end{array}$ & $\begin{array}{l}140 \pm 27 \\
(115-177)\end{array}$ & $\begin{array}{l}334 \pm 9 \\
(326-349)\end{array}$ & $\begin{array}{l}353 \pm 11 \\
(341-402)\end{array}$ & $\begin{array}{l}401 \pm 11 \\
(389-417)\end{array}$ \\
\hline Tail length & $\begin{array}{l}30 \pm 3 \\
(28-37)\end{array}$ & $\begin{array}{l}55 \pm 7 \\
(48-74)\end{array}$ & $\begin{array}{l}45 \pm 6 \\
(35-59)\end{array}$ & $\begin{array}{c}159 \pm 12 \\
(145-177)\end{array}$ & $\begin{array}{l}197 \pm 9 \\
(177-211)\end{array}$ & $\begin{array}{l}234 \pm 8 \\
(221-245)\end{array}$ \\
\hline
\end{tabular}

TABLE VI. Development of Rhabdias joaquinensis experimentally exposed to Acris crepitans. Free-living cultures established from wild Acris crepitans. Mean $\pm \mathrm{SD}$ (range) given in $\mu \mathrm{m}$, unless otherwise noted.

\begin{tabular}{|c|c|c|c|c|c|c|}
\hline & $\begin{array}{l}\text { Free-living } \\
\text { male }\end{array}$ & $\begin{array}{l}\text { Free-living } \\
\text { female }\end{array}$ & $\begin{array}{l}\text { Third stage } \\
\text { (infective) }\end{array}$ & $\begin{array}{l}\text { Adult } \\
\text { (lungs) }\end{array}$ & $\begin{array}{l}\text { Adult gravid } \\
\text { (lungs) }\end{array}$ & $\begin{array}{l}\text { Adult gravid } \\
\quad \text { (lungs) }\end{array}$ \\
\hline Days post-infection & - & - & - & 4 & 6 & 20 \\
\hline No. measured & 10 & 10 & 10 & 10 & 10 & 10 \\
\hline Total length & $\begin{array}{l}521 \pm 43 \\
(478-585)\end{array}$ & $\begin{array}{l}688 \pm 37 \\
(642-720)\end{array}$ & $\begin{array}{l}491 \pm 31 \\
(448-530)\end{array}$ & $\begin{array}{l}3.85 \pm 0.29 \mathrm{~mm} \\
\quad(3.3-4.0)\end{array}$ & $\begin{array}{l}3.95 \pm 0.12 \mathrm{~mm} \\
(3.7-4.25)\end{array}$ & $\begin{array}{l}4.11 \pm 0.08 \mathrm{~mm} \\
(3.81-4.18)\end{array}$ \\
\hline Maximum width & $\begin{array}{l}31 \pm 5 \\
(28-34)\end{array}$ & $\begin{array}{l}40 \pm 5 \\
(37-46)\end{array}$ & $\begin{array}{l}20 \pm 2 \\
(17-21)\end{array}$ & $\begin{array}{l}210 \pm 32 \\
(186-254)\end{array}$ & $\begin{array}{l}285 \pm 30 \\
(274-333)\end{array}$ & $\begin{array}{l}291 \pm 18 \\
(279-329)\end{array}$ \\
\hline Esophagus length & $\begin{array}{l}115 \pm 8 \\
(108-119)\end{array}$ & $\begin{array}{l}134 \pm 9 \\
(128-139)\end{array}$ & $\begin{array}{l}140 \pm 12 \\
(136-158)\end{array}$ & $\begin{array}{l}352 \pm 21 \\
(342-372)\end{array}$ & $\begin{array}{l}361 \pm 16 \\
(349-381)\end{array}$ & $\begin{array}{l}367 \pm 14 \\
(357-375)\end{array}$ \\
\hline Tail length & $\begin{array}{l}29 \pm 3 \\
(27-30)\end{array}$ & $\begin{array}{l}53 \pm 4 \\
(49-56)\end{array}$ & $\begin{array}{l}42 \pm 4 \\
(38-45)\end{array}$ & $\begin{array}{l}143 \pm 24 \\
(122-165)\end{array}$ & $\begin{array}{l}160 \pm 18 \\
(149-173)\end{array}$ & $\begin{array}{l}160 \pm 10 \\
(155-168)\end{array}$ \\
\hline
\end{tabular}

and urinary bladder. Then, worms penetrated into the body cavity and primarily resided near the lower lung as adults. Eventually adults penetrated into the lungs, where they fed on blood to become gravid. Adults in the body cavity were never gravid, nor contained fully developed eggs.

Timing of parasite development is provided in Figure 1. Rhabdias eustreptos juveniles developed quicker and reached greater size than Rh. fuscovenosa (see Tables II-III).

Rhabdias eustreptos released eggs in T. sauritus feces for 5, 9, and 9 mo; dead adults were shed in host feces starting 4 mo PI. Rhabdias fuscovenosa released eggs in T. sauritus feces for 7,11 , and $13 \mathrm{mo}$, the longest duration of any lungworm species; dead adult worms were recovered from host feces starting 5 mo PI.

For the first time, a non-gravid adult Rhabdias sp. was observed penetrating the lung of a host. Upon dissection of a snake infected in the laboratory with $R h$. eustreptos, a worm initiated penetration and completely entered into a semi-inflated lung. Penetration took place on the ventral, posterior section of the vascularized lung over a period of $3 \mathrm{~min}$; most of this time was dedicated to creating a small hole in the lung, through which the worm easily entered. Despite watching the worm enter through the hole, we struggled to locate the entry wound and noted few

TABLE VII. Development of Rhabdias ranae experimentally exposed to Rana pipiens. Free-living cultures established from wild Rana sphenocephala. Mean \pm SD (range) given in $\mu \mathrm{m}$, unless otherwise noted.

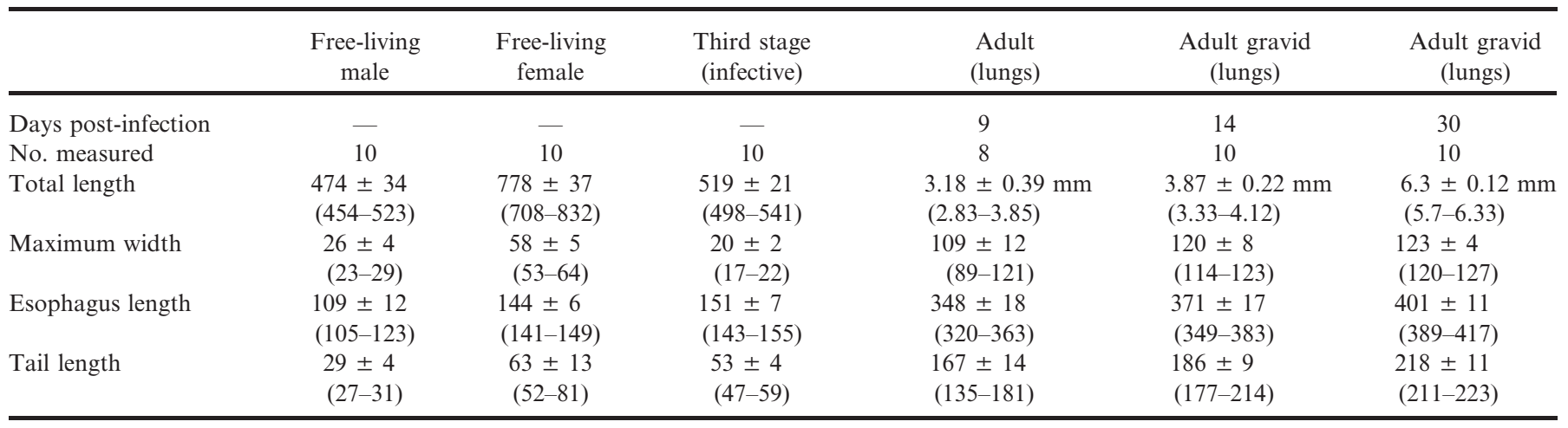



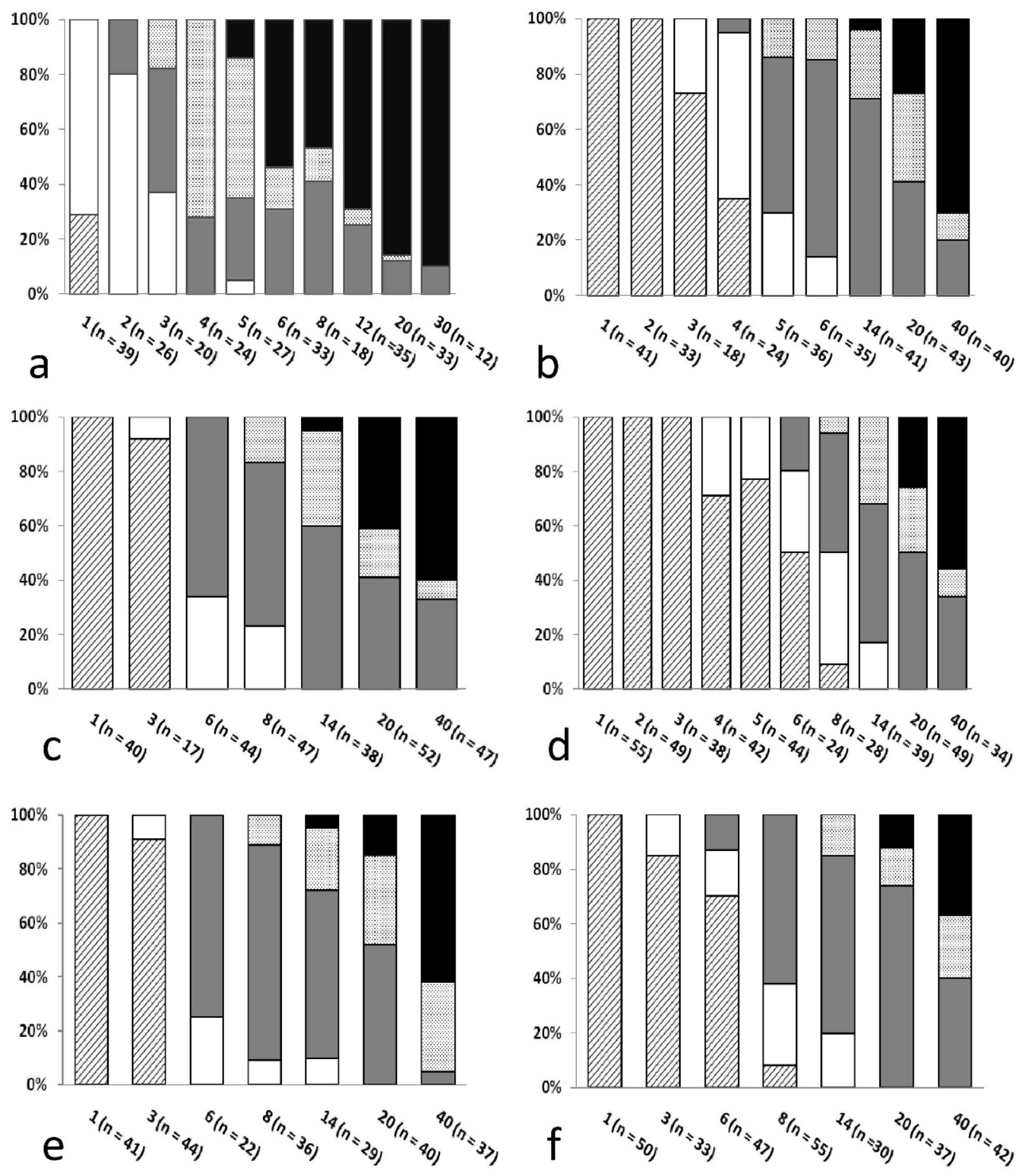

\section{Days (number of worms recovered)}

\section{3rd Stage $\square$ 4th Stage $\square$ Adult-body cavity $⿴ 囗 十$ Adult-lung $\square$ Adult-lung (gravid)}

Figure 1. Percentage of adult lungworms, (a) Rhabdias joaquinensis, (b) Rhabdias ranae, (c) Rhabdias bakeri, (d) Rhabdias americanus, (e) Rhabdias eustreptos, and (f) Rhabdias fuscovenosa, recovered during experimental infections of homologous anurans and snakes. 
signs of trauma to the surrounding lung tissue. Overall, it appeared penetration by a lungworm caused little immediate damage to lung tissue.

Lungworms of anurans: During skin exposure experiments, infective juveniles penetrated the skin of anurans to gain entry. Nematodes immediately reacted to the presence of a toad and, within minutes of exposure, were seen crawling on anuran skin. Per os infections were only established in $R h$. joaquinensis, i.e., 3 of 3 frogs established infections with 1, 1, and 2 worms collected. Infective juveniles were found both unharmed and viable in anuran feces from all 4 lungworm species. When not promptly removed, juveniles in these feces produced skin-penetrating infections, which could be easily mistaken for per os infections. Following skin penetration, all worms were found subcutaneously. Worms then migrated into the visceral fascia in the thoracic cavity, although some worms also remained subcutaneously in the pelvic region. Next, juvenile lungworms molted to fourth stage juveniles and penetrated into the body cavity where they developed into adults. Adults in the body cavity eventually penetrated into the lungs to feed on blood and become gravid. Adults in the body cavity were never gravid, nor did they contain fully developed eggs.

Timing of parasite development is provided in Figure 1. During skin exposures, $R h$. joaquinensis developed faster than any other species in this study, whereas $R h$. americanus juveniles developed the slowest, but reached the largest adult length of any species in this study (see Tables IV-VII). The mean total length of $R h$. bakeri gravid adults increased $3.02 \mathrm{~mm}$ in 13 days, which represented the greatest growth spurt of any lungworm species.

Of $12 \mathrm{~B}$. woodhousii maintained in the laboratory with $R h$. americanus infections, 8 survived to provide data on parasite longevity; worms from these toads released eggs for $13.4 \pm 1.7 \mathrm{wk}$ (range, 12-17 wk). Dead lungworms were found in feces starting at 10 wk PI. Four of $7 R a$. sylvatica maintained in the laboratory survived to provide data on parasite longevity. Rhabdias bakeri eggs were released in $R a$. sylvatica feces for 10-16 wk. Dead adults were occasionally passed in host feces starting at 8 wk PI. Rhabdias joaquinensis from $A$. crepitans released eggs for the shortest time period of any lungworm species, $34.5 \pm 5.7$ days (range, 24 45 days). Dead adults were occasionally passed in host feces starting 24 days PI. Finally, $R h$. ranae from $R a$. blairi released eggs in host feces for $15 \pm 4.3 \mathrm{wk}$ (range, 12-20 wk). Dead adult worms were found in host feces starting 8 wk PI.

\section{Transport hosts}

Lungworms of snakes: Physid snails when exposed to both species of snake lungworms, Rh. eustreptos (prevalence $=63 \%$, mean intensity $=2.1 \pm 1.1, \mathrm{n}=7$ ) and $R h$. fuscovenosa (prevalence $=57 \%$, mean intensity $=3.4 \pm 2.6, \mathrm{n}=7$ ), produced infective juveniles. Worms were recovered from tissues of the snail's foot; they appeared as healthy third stage juveniles and, when fed to snakes, normal infections resulted. With $R h$. eustreptos, 2 of 3 snakes became infected with 2 and 5 lungworms when fed transport host snails. For Rh. fuscovenosa, 3 of 3 snakes became infected with 1,3 , and 4 lungworms following snail consumption.

The earthworm Eisenia foetida and frog Ra. blairi also hosted dormant third stage juveniles of both snake lungworm species and served as suitable transport hosts. Earthworms harbored $R h$. eustreptos (prevalence $=63 \%$, mean intensity $=5.2 \pm 3.2, \mathrm{n}=7$ ) and $R h$. fuscovenosa (prevalence $=33 \%$, mean intensity $=3.4 \pm$ $3.2, \mathrm{n}=7$ ); juvenile worms were collected from the coelom and intestine. In Rh. eustreptos, 3 of 3 snakes became infected with 1 , 2 , and 7 lungworms when fed transport host earthworms, whereas 2 of 3 snakes exposed to earthworms that harbored $R h$. fuscovenosa each became infected with 2 lungworms. Infective juveniles were found subcutaneously in the frog $R a$. blairi, primarily in the hind legs. Frogs acted as transport hosts for $R h$. eustreptos (prevalence $=44 \%$, mean intensity $=6.4 \pm 4.5, \mathrm{n}$ $=7$ ) and $R$. fuscovenosa (prevalence $=73 \%$, mean intensity $=$ $4.5 \pm 1.3, \mathrm{n}=7$ ). Three of 3 snakes fed frogs serving as transport hosts for Rh. eustreptos became infected with 2, 3, and 6 lungworms. Of 3 snakes exposed to frogs serving as transport hosts for Rh. fuscovenosa, $100 \%$ became infected with 1, 3, and 3 lungworms.

Juvenile lungworms did not penetrate Tenebrio molitor, nor did infections result when snakes were fed beetles exposed to either lungworm species. None of the time- 0 or time-T control snakes, snails, frogs, earthworms, or beetles were infected.

Lungworms of anurans: This study was able to establish infections in anurans that resulted from using snails as transport hosts for Rh. americanus in B. woodhousii (prevalence $=43 \%$, mean intensity $=2.3 \pm 2.3, \mathrm{n}=7$ ) and $R h$. joaquinensis in $A$. crepitans (prevalence $=50 \%$, mean intensity $=2.6 \pm 2.1, \mathrm{n}=6$ ). Rhabdias bakeri and $R h$. ranae were not tested during transport host experiments due to a lack of appropriate anuran hosts. Infections were not established in anurans fed earthworms or beetles. In terms of lungworm penetration into potential transport hosts, $R$ h. joaquinensis (prevalence $=73 \%$, mean intensity $=4.8$ $\pm 2.2, \mathrm{n}=7$ ) and $R h$. americanus (prevalence $=81 \%$, mean intensity $=6.7 \pm 2.5, \mathrm{n}=7$ ) penetrated into the foot of $P$. gyrina. The study also recovered $R h$. joaquinensis (prevalence $=16 \%$, mean intensity $=2.9 \pm 1.2, \mathrm{n}=7$ ) and $R h$. americanus (prevalence $=10 \%$, mean intensity $=2.3 \pm 0.5, \mathrm{n}=7$ ) third stage juveniles from the coelom of the earthworm E. foetida. Worms recovered from earthworms and snails appeared unchanged and viable. Anuran lungworms were unable to penetrate T. molitor. No time- 0 or time-T control anurans, snails, earthworms, or beetles were infected.

\section{DISCUSSION}

\section{Initial commentary}

This study is the first to establish several life history characteristics for anuran and snake lungworms, including data on fecundity and developmental rates. These results should provide valuable data for future ecological and evolutionary studies on lungworms and other nematodes. However, the primary contribution of this comparative study is the establishment of different life cycles and life history strategies between snake and anuran lungworms, adding species of Rhabdias to the list of studies that have identified life cycle variation (see Introduction). These results strengthen suggestions that life cycle variation within closely related parasites is more common than initially thought (e.g., Morand and Poulin, 2003; Bolek and Janovy, 2007a, 2007b; Poulin, 2007; Bolek et al., 2009). It is clear that more studies are needed to determine how widespread life cycle variation is within, and among, parasite taxa, and to 
understand the role life cycle variation plays in parasite evolution. For example, our understanding of life cycle evolution in lungworms would benefit from a phylogenetic analysis to determine whether variation in life cycle and life history data are congruent with Rhabdias evolution, i.e., snake and anuran lungworms form separate clades.

\section{Free-living experiments}

In the present study, eggs released from adult worms in the lungs of anuran hosts were fully embryonated, whereas lungworm eggs from snakes were not fully embryonated until they reached the snake's colon. The difference in lung embryonation rates of anuran and snake species may be attributable to gastrointestinal length and differences in defecation patterns between host groups. Anurans tend to have short intestines and in nature defecate at least once every $24 \mathrm{hr}$ (G. Langford, pers. obs.), whereas snakes have longer gastrointestinal tracts and inconsistent feeding patterns; as a consequence, many snakes only defecate 1-4 times per month (Secor and Diamond, 1995; Overgaard et al., 2002). Thus, it appears that lungworms of anurans are continuously released into the external environment compared to the lungworms infecting snakes. Under these conditions, our observations suggest anuran lungworms require rapid embryonation to ensure eggs hatch upon exposure to the external environment. In contrast, selective pressures on embryonation may be relaxed in snake lungworm species because most eggs accumulate in the snakes' colon for several days prior to being evacuated into the external environment. Baker (1979) suggested that rapid hatching of free-living juveniles upon exposure to the external environment is vital for lungworm survival given that eggs lack resistance to environmental fluctuations. In agreement, we found that unhatched eggs of all lungworms are susceptible to desiccation and predation in culture chambers, likely making environmental embryonation a risky venture in nature.

Free-living female lungworms produce varying numbers of eggs based on host affinities. Lungworms from snakes produce 8-10 eggs per individual female worm, whereas worms from anurans only produce $2-3$ eggs. The disparity in egg production between worms infecting snakes and anurans is perplexing, especially considering free-living females from all species are similar in size, developmental period, and habitat, i.e., feces and soil. Given these similarities, we would expect free-living lungworms to produce similar numbers of offspring, according to maximum fecundity studies conducted by Morand (1996). However, Chu (1936) was unable to infect snake hosts with infective juveniles produced during heterogonic reproduction, leading Baker (1979) to suggest that indirect development may be vestigial in snake lungworms. The present study found a small proportion $(<2 \%)$ of juveniles in snake lungworms unable to develop heterogonically, or to infect snakes, an observation that supports Baker's assertion that heterogonic reproduction is vestigial in snake lungworms. If heterogonic development is vestigial, then few evolutionary forces are expected to constrain egg production in snake lungworms. Therefore, comparing egg production between snake and anuran lungworms may have little evolutionary significance.

Homogonic, or direct, development of free-living juveniles was first described in snake lungworms by Railliet (1899), and later confirmed by Goodey (1924), Chu (1936), and Baker (1979). Our studies on the free-living stages of North American lungworms indicate that homogonic and heterogonic development can both, but do not always, occur in species infecting anurans and snakes, with a single dominant form of development in each species. Homogonic development predominated in lungworms that infect snakes, whereas lungworms of anurans develop entirely heterogonically, except for a limited number of $R h$. joaquinensis. Williams (1960) also found homogonic development in another anuran lungworm, Rhabdias sphaerocephala. Again, the evolutionary importance of the non-dominant form of development is unclear, because we were unable to establish infections with nondominant infective juveniles of any species. Baker's (1979) suggestion that non-dominant forms are vestigial may explain why these juveniles are uninfective; alternatively, it is possible that non-dominant forms can establish infections under conditions not reproducible in the laboratory.

\section{Host experimental exposures}

The route of transmission, i.e., oral versus skin penetration, prior to the present study was an unsettled issue in Rhabdias spp. biology. Previous researchers agreed that lungworms infecting amphibians primarily gain entry through pores in amphibians' moist, glandular skin (Fulleborn, 1928; Schaake, 1931; Williams, 1960; Baker, 1979), but the status of oral exposure as a viable route of infection in amphibian lungworms was unknown (Baker, 1979). In snake lungworms, Chu (1936) was only able to infect snakes orally, and he suggested that infective juveniles were unable to penetrate the thick, dry skin of snakes. However, when Chu (1936) injected infective juveniles subcutaneously into snakes, normal infections occurred, thus supporting his assertion that the dry, scaly property of snakeskin is the constraining factor preventing cutaneous penetration in snake lungworms.

The present study confirms that snake lungworms are unable to penetrate reptilian skin, and suggests that oral inoculation is the primary, and likely only, route used by snake lungworms. Thus, upon per os inoculation, snake lungworms immediately began penetrating into esophageal tissue, which is mechanically amenable to nematode penetration. Our study found esophageal penetration by snake lungworms was similar to skin penetration by those infecting anuran, including preferred penetration at, or near, a mucus gland (as described below). Subsequent to esophageal penetration, an active fascia and body cavity migration occurs in the snake host (Goodey, 1924; Chu, 1936; this study). In agreement with Goodey (1924) and Chu (1936), our study observed 2 molts during the migration of snake lungworms through the body cavity. The first molt was shed by fourth stage juveniles, while the second molt was retained by the mature adult as a sheath. Chu (1936) found an identical molting pattern in $R h$. fuscovenosa, whereas Goodey (1924) observed both molts being retained as sheaths.

When anurans were exposed to 4 homologous species of lungworms by pipetting infective juveniles into their esophagus, only $R h$. joaquinensis established infections; however, all species became infected when juveniles were pipetted into the mouth. These observations suggest anurans can become infected by ingesting juveniles in the soil or present externally on a prey item, which would result in a skin-penetrating infection near the margin of the mouth. Infective worms that bypass the oral cavity, i.e., worms inside of a transport host, appear to be less likely to establish infections, except in $R h$. joaquinensis, which consistently 
established low intensity infections in our experiments. However, the present study was unable to completely rule out skin penetration by $R h$. joaquinensis, since infective worms may have migrated out of the esophagus or cloaca, resulting in skinpenetrating infections.

The present study observed skin-penetrating ability by all 4 species of anuran lungworms. When worms were placed in the vicinity of a host they become markedly more active and immediately began to search for the host. Infective juveniles appeared to use a combination of physical stimuli, i.e., host vibrations and chemotaxis, to locate hosts. Upon physically encountering a host, worms generally undulated over host skin for 1-2 min, near the lower limbs or underbelly of the host prior to initiating penetration, except in $R h$. americanus infecting adult toads, where penetration almost always occurred on, or near, the seed patch. Our observations suggest that the thick cuticle of an adult toad's lower appendages is a poor site for worm penetration. Schaake (1931) suggested worms gained host entry through the numerous pores associated with amphibian mucous glands. In our experience, worms almost always penetrated at a mucous gland, which appears to facilitate dermal penetration. Generally, penetration and entry lasted approximately 2-3 min, although some worms entered extremely rapidly, without much apparent resistance.

Internal migration by amphibian lungworms was first proposed by Fulleborn (1928) and Schaake (1931). Both authors mistakenly thought juveniles were dispersed throughout the body via the circulatory system, and eventually reached the lungs and matured to adults. Subsequent studies have conclusively shown that infective worms undergo a body migration that does not involve the circulatory system (Williams, 1960; Baker, 1979; this study). Following penetration, we found worms residing in the fascia, where they undergo an incomplete molt by retaining the sheath. Next, worms penetrated the fascia and entered into the body cavity, which was followed by a complete molt to adulthood. In agreement with Baker (1979), our study found that both the third and fourth stage cuticles are shed simultaneously. Finally, worms penetrated the lungs and fed on blood to become gravid adults.

\section{Transport host experiments}

The potential for transport hosts in the transmission of lungworms has been suspected since Fulleborn (1928) suggested that gastropods could serve as paratenic hosts for $R h$. americanus. Previous studies have exposed snake and anuran lungworms to potential transport hosts to determine the ability of lungworms to penetrate into these hosts (Fulleborn, 1928; Chu, 1936; Baker, 1979). Chu (1936) reported that when Rh. fuscovenosa was fed to tadpoles, snails, copepods, and adult anurans, juvenile worms were passed unharmed in the feces and did not penetrate into the tissue of these animals. Fulleborn (1928) and Baker (1979) reported that anuran lungworms are capable of penetrating into snail tissue, and the latter author found a single instance of $R h$. fuscovenosa penetrating into toads. However, no study has attempted to feed exposed transport hosts to homologous lungworm hosts.

In the present study, both snake and anuran lungworms were capable of using transport hosts to establish infections in homologous host species in the laboratory. However, our results show lungworms vary in their ability to use transport hosts. Thus, anuran lungworms were able to use only snails as successful transport hosts, whereas snake lungworms were capable of using a variety of transport hosts, including frogs, earthworms, and snails. This study does not demonstrate infections of transport hosts in nature; however, snakes feed on a variety of prey items (Ernst and Ernst, 2003), including those used in this experiment. In addition, transport hosts used in this experiment are known to feed directly upon or near vertebrate feces (Campbell and Little, 1988; Bohlen and Edwards, 1995), which provide snake lungworms opportunities to penetrate potential transport hosts in nature. These observations suggest that snake lungworms may use transport hosts more frequently than anuran lungworms to complete their life cycle. Snake lungworms rely on oral exposure to infect hosts (Chu, 1936; this study); therefore, the ability to penetrate host prey items should facilitate transmission to the final host, providing a viable evolutionary avenue for snake lungworms.

Conversely, skin-penetrating anuran lungworms in our study appear to have little use for an oral transmission route because when infective juveniles enter a transport host their ability to encounter anuran epidermal tissue is drastically reduced, if not eliminated. Anuran lungworms in this study were poorly adapted to penetrating into the intestinal tract of anurans (see per os infections); transport host infections result when infective juveniles migrate out of the intestinal tract, resulting in skinpenetrating infections near the margin of the mouth or cloaca. The large number of lungworms that pass (alive and dead) in feces following per os and transport host experiments support our assertion that anuran lungworms in this study are poorly adapted to oral routes of infection. The low prevalence and intensity of infections in these experiments make it unlikely transport hosts serve as an evolutionary avenue of infection for anuran lungworms. Nevertheless, other anuran lungworm species may use transport hosts successfully in nature if their anuran host(s) consume large numbers of semi-aquatic snails and/or display a greater propensity for intestinal penetration than found in this study.

\section{ACKNOWLEDGMENTS}

The authors acknowledge Matthew Bolek, Oklahoma State University, Stillwater, Oklahoma, for providing specimens of $R h$. americanus, $R h$ bakeri, and $R h$. ranae from Wisconsin for comparison. Additionally, G.J.L. thanks Melanie Langford, Nic Langford, Joel Borden, Matthew Bolek, and Scott Snyder for help in collecting amphibians and reptiles; David Nelson, Mark Woodrey, and the U.S. Forest Service for help locating and/or accessing field sites; Melanie Langford and 2 anonymous reviewers for improving early drafts of this manuscript; and Cedar Point Biological Station, Grand Bay National Estuarine Research Reserve, and the University of South Alabama Vertebrate Museum for providing facilities. This work was supported by grants from the National Oceanic and Atmospheric Administration's National Estuarine Research Reserve Fellowship, and the School of Biological Sciences Special Funds, University of Nebraska-Lincoln, Lincoln, Nebraska.

\section{LITERATURE CITED}

BAKER, M. R. 1979. The free-living and parasitic development of Rhabdias spp. (Nematoda: Rhabdiasidae) in amphibians. Canadian Journal of Zoology 57: 161-178.

Bohlen, P. J., and C. A. Edwards. 1995. Earthworm effects on N dynamics and soil respiration in microcosms receiving organic and inorganic nutrients. Soil Biology and Biochemistry 27: 341-348.

BoleK, M. G., AND J. JANOVY, JR. 2007a. Small frogs get their worms first: The role of non-odonate arthropods in the recruitment of Haema- 
toloechus coloradensis and Haematoloechus complexus in newly metamorphosed northern leopard frogs, Rana pipiens, and Woodhouse's toads, Bufo woodhousii. Journal of Parasitology 93: 300-312. , AND —. 2007b. Evolutionary avenues for and constraints on the transmission of frog lung flukes (Haematoloechus spp.) in dragonfly second intermediate hosts. Journal of Parasitology 93: 593-607.

— AND - 2008. Alternative life cycle strategies of Megalodiscus temperatus in tadpoles and metamorphosed anurans. Parasite 15: 396-401.

- S. D. SNYder, And J. JANOvY, JR. 2009. Alternative life cycle strategies and colonization of young anurans by Gorgoderina attenuata in Nebraska. Journal of Parasitology 95: 604-616.

Campbell, B. G., And M. D. Little. 1988. The finding of Angiostrongylus cantonensis in rats in New Orleans. American Journal of Tropical Medicine and Hygiene 38: 568-573.

Christin, M. S., A. D. Gendron, P. Brousseau, L. Menard, D. J Marcogliese, D. Cyr, S. Ruby, and M. Fournier. 2003. Effects of agricultural pesticides on the immune system of Rana pipiens and on its resistance to parasitic infection. Environmental Toxicology and Chemistry 22: $1127-1133$

Chu, T. 1936. Studies on the life history of Rhabdias fuscovenosa var. catanensis (Rizzo, 1902). Journal of Parasitology 22: 140-160.

Dare, O., And M. Forbes. 2008a. Rates of development in male and female wood frogs and patterns of parasitism by lung nematodes. Parasitology 135: 385-393.

- AND - 2008b. Patterns of infection by lungworms, Rhabdias ranae and Haematoloechus spp. in northern leopard frogs: A relationship between sex and parasitism. Journal of Parasitology 95: $275-280$.

Ernst, C. H., And E. M. Ernst. 2003. Snakes of the United States and Canada. Smithsonian Books, Washington, D.C., 668 p.

Fuellborn, F. 1928. Ueber den infektionsweg bei Rhabdias bufonis (Rhabdonema nigrovenosum) des frosches nebst versuchen uber die lymphzirkulation des letzteren. Zentralblatt Bakteriologie Parasitenkunde Infektioskrankheiten 109: 444-462.

Gendron, A. D., D. J. Marcogliese, S. Barbeau, M. S. Christin, P. Brousseau, S. Ruby, D. Cyr, and M. Fournier. 2003. Exposure of leopard frogs to a pesticide mixture affects life history characteristics of the lungworm Rhabdias ranae. Oecologia 135: 469-476.

GoAter, C. P. 1992. Experimental population biology of Rhabdias bufonis (Nematoda) in toads: Density-dependence in the primary infection. Parasitology 104: 179-187.

. 1994. Growth and survival of post-metamorphic toads: Interactions among larval history, density, and parasitism. Ecology 75: 2264-2274

, AND P. I. WARD. 1992. Negative effects of Rhabdias bufonis (Nematoda) on the growth and survival of toads (Bufo bufo). Oecologia 89: 161-165.

Goodey, T. 1924. The anatomy and life history of Rhabdias fuscovenosa (Railliet) from the grass snake Tropidonotus natrix. Journal of Helminthology 2: 51-64.

Heyer, W. R., M. A. Donnelley, R. W. McDiarmid, L. A. C. Hayek, AND M. S. Foster. 1994. Measuring and monitoring biological diversity: Standard methods for amphibians. Smithsonian Institution Press, Washington, D.C., 364 p.
Kuzmin, Y., V. V. TKach, AND S. D. SNYder. 2003. The nematode genus Rhabdias (Nematoda: Rhabdiasidae) from amphibians and reptiles of the Nearctic. Comparative Parasitology 70: 101-114.

Lefebvre, F., And R. Poulin. 2005. Progenesis in digenean trematodes: A taxonomic and synthetic overview of species reproducing in their second intermediate hosts. Parasitology 130: 587-605.

MeczniKow, I. I. 1865. Ueber die enteickelung von Ascaris nigrovenosa. Archives Physiologie und Anatomie Abstract: 409-420.

Morand, S. 1996. Life-history traits in parasitic nematodes: A comparative approach for the search of invariants. Functional Ecology 10: 210-218.

-, AND R. Poulin. 2003. Phylogenies, the comparative method and parasite evolutionary ecology. Advances in Parasitology 54: 281302.

Overgaard, J., J. B. Anderson, And T. Wang. 2002. The effects of fasting duration on the metabolic response to feeding in Python molurus: An evaluation of the energetic costs associated with gastrointestinal growth and upregulation. Physiological and Biochemical Zoology 75: 360-368.

Pough, F. H., R. M. Andrews, J. E. Cadle, M. L. Crump, A. H. Savitzky, and K. D. Wells. 2004. Herpetology, 2nd ed. Pearson Education Inc., Upper Saddle River, New Jersey, 726 p.

Poulin, R. 2007. Evolutionary ecology of parasites, 2nd ed. Princeton University Press, Princeton, New Jersey, $332 \mathrm{p}$

Prichard, M. H., and G. O. W. Kruse. 1982. The collection and preservation of animal parasites. University of Nebraska Press, Lincoln, Nebraska, $141 \mathrm{p}$.

Railliet, A. 1899. Evolution sans heterogonie d'un Angiostome de la Couleuvre a collier. Comptes Rendus de l'Académie des Sciences 129: $1271-1273$

Runey, W. M., G. L. Runey, and F. H. Lauter. 1978. Gametogenesis and fertilization in Rhabdias ranae Walton 1929: I. The parasitic hermaphrodite. Journal of Parasitology 64: 1008-1014.

SchaAKe, M. 1931. Infektionsmodus und infektionsweg der Rhabdias bufonis Schrank (Angiostomum nigrovenosum) und dei metamorphose des genitalapparates der hermaphroditischen generation. Zeitschrift fur Parasitenkunde 3: 517-648.

Secor, S. M., and J. Diamond. 1995. Adaptive responses to feeding in Burmese pythons: Pay before pumping. Journal of Experimental Biology 198: 1313-1325.

SNyder, S. D., and J. Janovy, JR. 1994. Second intermediate hostspecificity of Haematoloechus complexus and Haematoloechus medioplexus (Digenea: Haematoloechidae). Journal of Parasitology 80: 1052-1055.

Spieler, M., and E. Schierenderg. 1995. On the development of the alternating free-living and parasitic generations of the nematode Rhabdias bufonis. Invertebrate Reproduction and Development 28: 193-203.

Stiles, C. W., and A. Hassal. 1905. Index catalogue of medicine and veterinary zoology. Bulletin 114, U.S. Public Health Service, Washington, D.C., 324 p.

Walton, A. C. 1929. Studies on some nematodes of North American frogs. Journal of Parasitology 15: 227-240.

Williams, R. W. 1960. Observations of the life history of Rhabdias sphaerocephala Goodey 1924 from Bufo marinus L., in the Bermuda Islands. Journal of Helmintology 34: 93-98. 